\title{
Impact of historical tsunamis on a sandy coastal barrier: an example from the northern Gargano coast, southern Italy
}

\author{
F. Gianfreda ${ }^{1}$, G. Mastronuzzi ${ }^{2}$, and P. Sansò ${ }^{3}$ \\ ${ }^{1}$ Geo Data Service, Via Schilardi 16, Maglie, Lecce, Italy \\ ${ }^{2}$ Dipartimento di Geologia e Geofisica, Università di Bari, Italy \\ ${ }^{3}$ Osservatorio di Chimica, Fisica e Geologia ambientale, Dip. Scienza dei Materiali, Università di Lecce, Italy
}

Received: 30 July 2001 - Revised: 19 December 2001 - Accepted: 8 January 2002

\begin{abstract}
The Lesina coastal barrier is characterized by the presence of three wide washover fans. They were formed by three distinct tsunamis which struck the northern coast of the Gargano Promontory (Apulia, Italy) during historical times. A model for their formation is presented. It takes into account the geomorphological data collected and some reports about the effect of recent tsunamis on coastal barriers and beaches. Washover fans were produced by tsunami waves which ran through coseismic cracks developed on dune ridges shaping a narrow, straight and relatively deep trench which constitutes the fan throat. Moreover, each tsunami event most likely caused severe erosion of the coastal barrier, shaping erosive grooves across the dune ridges, causing beach cliffs and causing the nourishment of submarine offshore bars. After the tsunami, a phase of coastal barrier recovery began, forming new dune ridges and closing washover fan throats. Morphological, archeological and radiometric data indicate a pre-Roman age for the oldest event, which was dated at 2430 years BP. The second tsunami struck the Lesina coastal barrier with similar magnitude 1550 years BP; it was caused by the strong earthquake that occurred at Gargano Promontory in the year $493 \mathrm{AD}$ as reported by a medieval sacred legend. The smallest and more recent fan formed following the tsunami that hit the northern coast of Gargano on 30 July 1627.
\end{abstract}

Key words. Tsunami, coastal barrier evolution, washover fan, Apulia, Italy

\section{Introduction}

The Gargano Promontory is the most uplifted area of the Apulian foreland. It is the emerged part of a plate constituting the foreland of both the east-verging Apenninic and west-verging Dinaric orogens (Fig. 1). It is known to have been affected by several violent earthquakes during historical times, with epicenters localised in both inland and offshore

Correspondence to: P. Sansò (paolo.sanso@unile.it) areas. A detailed study of historical sources provides a complete record of recent earthquakes, some of which were accompanied by devastating tsunamis (Tinti et al., 1995). The largest one occurred on 30 July 1627 . It was generated by an intensity-XI earthquake that caused severe damage and many victims (Molin and Margottini, 1981; Guidoboni and Tinti, 1987). A numerical simulation performed by Tinti and Platanesi (1996) suggests that a generative fault located inland caused the uplift of the sea block facing the Lesina Lake. Historical sources (Molin and Margottini, 1981) report that the coastal waters withdrew first as much as $3 \mathrm{~km}$ and then overflowed into the lake. Regarding the Lesina Lake area, it was most likely affected by coseimic vertical movements, as chronicles report that the earthquake "raised the lake bottom twofold", whereas Lesina village, on the landward bank of the lake, underwent coseimic subsidence.

Minor tsunami events were reported on 31 May 1646, 20 March 1731, 22 October 1756, 8 December 1889 and $10 \mathrm{Au}-$ gust 1893 (Tinti et al., 1995).

In this paper, the first results of the geomorphological analysis on the sandy coastal barrier that divides the coastal lake of Lesina from the Adriatic Sea are reported. The effects of three distinct tsunamis that struck the northern coast of the Gargano Promontory are described, along with their chronology assessed using AMS radiocarbon datings.

\section{The geomorphological impact of tsunamis on coastal zone}

Tsunamis can greatly influence coastal evolution and landforms assemblage. The main effects of tsunamis on rocky coasts are represented by the detachment of large boulders in the nearshore zone and their deposition farther inland (Dawson, 1994; 1999; 2000), and also by the sculpturing of bedrock with the formation of smooth, small-scale forms and large-scale features (Bryant and Young, 1996). Commonly, large boulder deposition has been observed along numerous coastal tracts. Bourrouilh-Le Jan and Talandier (1985) refer 


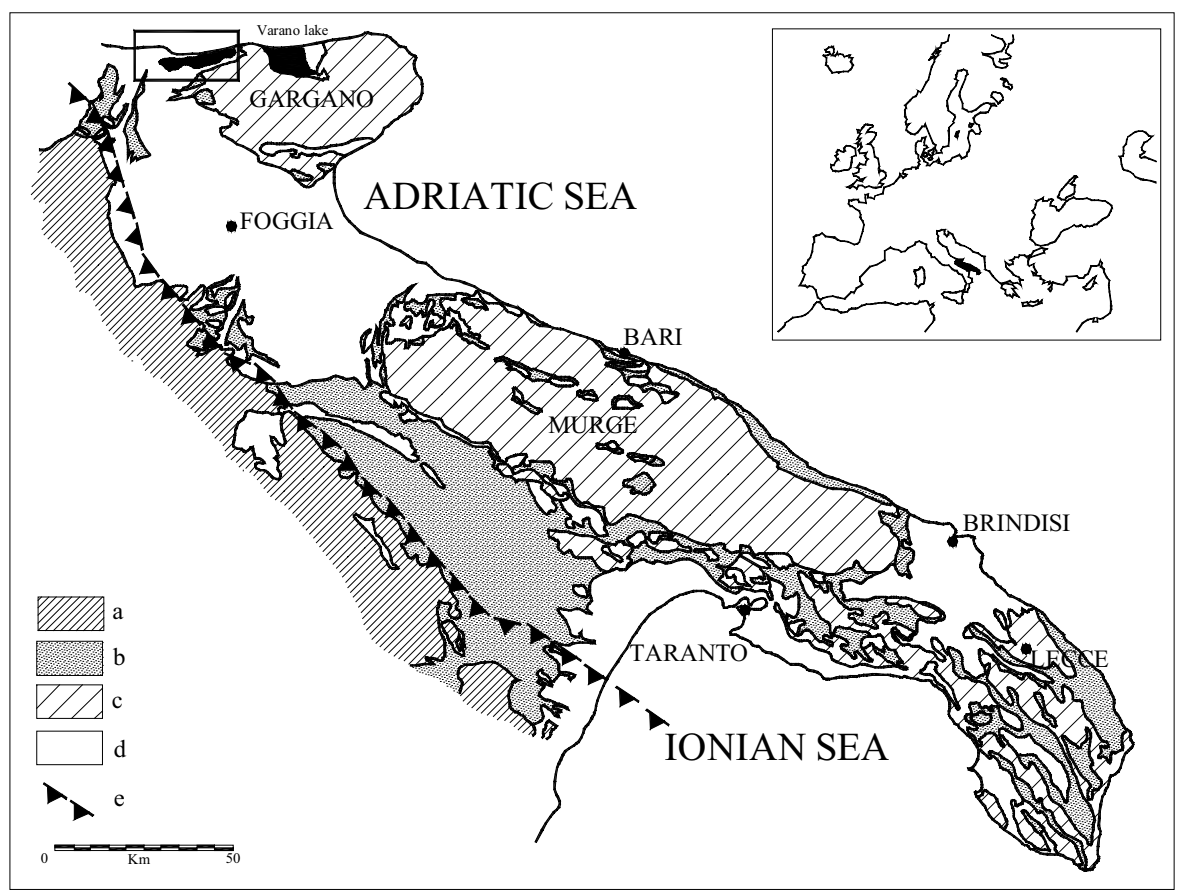

Fig. 1. Geological map of Apulia region. The position of the Lesina coastal barrier is marked by a box. Legend: (a) Apenninic Chain units; (b) Apenninic foredeep units; (c) Apulian foreland units; (d) Quaternary units; (e) Apenninic fold limit. to the dislocation of $15 \times 10 \times 5 \mathrm{~m}$ blocks onto reef flats by catastrophic events (tsunamis or hurricanes) at Rangiroa, Tuamotum, SE Pacific. Boulders, considered to be deposited during the last interglacial period by a tsunami, occur within a $8 \mathrm{~m}$ thick deposit on the islands of Lanai and Molokai, Hawaii (Moore and Moore, 1984; 1988). Giant blocks up to about $100 \mathrm{~m}^{3}$ in volume were deposited up to $30 \mathrm{~m}$ above present sea level by a tsunami during the Holocene, at the Ryukyu Islands, Japan (Nakata and Kawana, 1993). Deposits of large, imbricated and aligned boulders placed above the present-day limit of storm waves have been detected along the coast of southern New South Wales; these boulders were deposited by a tsunami that approached the coast from SE to SSE about 9.5 ka BP (Young et al., 1996; Bryant et al., 1996). In the Bahamas, Hearty (1997) and Hearty et al. (1998) report boulders measuring 100 to $1000 \mathrm{~m}^{3}$ in volume scattered by a tsunami or extreme storms along the coast of North Eleuthera Island during Oxygen Isotopic Stage 5e or 5d (about 125$110 \mathrm{ka}$ BP). Along the Mediterranean coast, large imbricated slabs of Pleistocene calcarenites were carved and scattered along the Ionian coast of Apulia (southern Italy). Their presence is related to a tsunami that was most likely caused by a landslide triggered by the 4 December 1456 earthquake (Mastronuzzi and Sansò, 2000).

Studies regarding the morphological effects of tsunamis on coastal barriers are fewer. Tsunamis produced $40 \mathrm{~m}$ wide, several metres high ridges stretching parallel to the coastline of South Ryukyu Islands, Japan (Ota et al., 1985). On the island of Lanai, Hawaii, dunelike gravel ridges developed during episodes of exceptionally rapid water movements (Moore and Moore, 1988). Andrade (1992) detected the effects of the Lisbon tsunami of 1755 AD on the Ria Formosa Barrier
Islands, Algarve region, Portugal. He recorded widespread submergence, barrier breaching and the formation of large washover fans, as well as the complete reorganization of the backbarrier drainage system.

Further data come from reports in regions recently struck by tsunamis. Detailed observations of the 26 May 1983 tsunami that impacted the coast of northeast Japan are reported by Minoura and Nakaya (1991). Incoming and outgoing tsunami waves eroded large volumes of beach and dune sands which finally accumulated in the shoreface region forming submarine bars. Beaches subsequentely widened due to the effective nourishment by reworked sands. Furthermore, the seismic shock triggered the formation of cracks on beaches and in beach-ridge dunes. Some of these cracks developed into long gashes connecting interdune ponds to the Japan Sea. Large volumes of sea water rushed into the ponds through the gashes, depositing a thin layer of beach and dune sand on the bottom of the ponds. The 1993 Southwest Hokkaido and 1983 Japan Sea tsunamis deposited thick and widespread sand sheets derived from beaches and coastal dunes (Sato et al., 1995). At Aonae, Okushiri Island, the 1993 event eroded grooves several metres in diameter with a maximum depth of $40 \mathrm{~cm}$. On 3 June 1994, Java tsunami produced escarpments up to $1.8 \mathrm{~m}$ high along main beaches at the south-southeastern coast of the island (Maramai and Tinti, 1997). Finally, McSaveney et al. (2000) report that the 17 July 1988 Papua New Guinea tsunami caused at the spit that divides Sissano Lagoon from the open sea, sand deposition exceeding $1 \mathrm{~m}$ on the seaward beach ridge, as well as scour holes up to $2 \mathrm{~m}$ deep, occurred. 


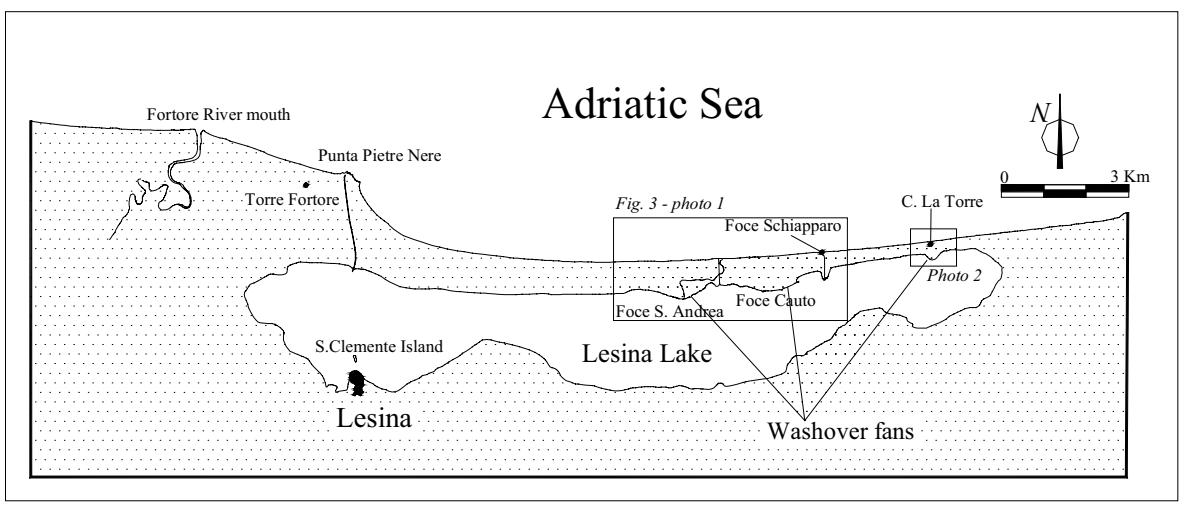

Fig. 2. Geographic position of the Lesina coastal barrier and washover fans.

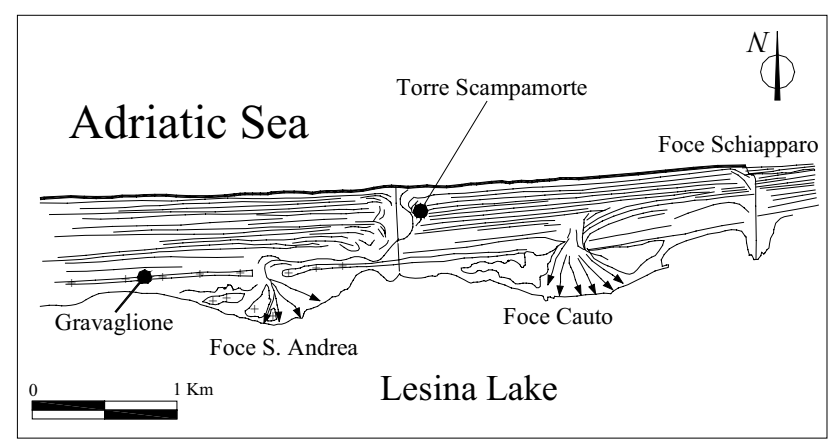

Fig. 3. Dune ridges and washover fans on the Lesina coastal barrier in the area of S. Andrea and Foce Cauto.

\section{The morphology of Lesina coastal barrier}

The Lesina and Varano coastal barriers and lakes display a favourable geomorphological setting to preserve a record of the effects related to tsunamis that struck the northern coast of Apulia during the last three thousands years. This paper presents the first results of a geomorphological survey of the Lesina coastal barrier, aiming to detect the impact of tsunami events and coseismic movements on the coastal landscape evolution.

Archaeological and historical data allow for the age of Lesina and Varano coastal barriers to be estimated. The Lesina Lake barrier is the older of the two barriers since it was most likely developing during the Bronze Age and its formation was completed during Roman times (Gravina, 1995). The Varano Lake barrier was open during Roman times, but closed between the V and VII centuries AD (Alvisi, 1970). The Lesina Lake is elongated parallel to the shoreline with a length of $22 \mathrm{~km}$ and a width of 1.8 to $3.0 \mathrm{~km}$. The lake salty waters reach the maximum depth of about $1.9 \mathrm{~m}$. The Lesina Lake is divided from the Adriatic Sea by a continuous sandy coastal barrier characterized by mean elevation of about $3 \mathrm{~m}$ above m.s.l., reaching the maximum height of about $8 \mathrm{~m}$ at Gravaglione. It measures $1400 \mathrm{~m}$ in width at its western end to a minimum of $350 \mathrm{~m}$ to the east (Fig. 2). Two artificial channels connect the lake with the
Adriatic Sea.

The Lesina coastal barrier can be morphologically subdivided into three parallel strips. The oldest is represented by the remnants of a high dune belt marking the landward border of the coastal barrier near Gravaglione. A washover fan at Foce S. Andrea breaks the lateral continuity of this ridge. The fan spreads over a radius of $500 \mathrm{~m}$ with its throat closed seaward by a more recent dune belt (Fig. 3). On the surface of the fan, structures from the Roman age have been found. The second strip is about $300 \mathrm{~m}$ wide and is characterized by widely-spaced, degraded dunes punctuated by shallow grooves without preferential spatial orientation. This last zone is broken by the Foce Cauto washover fan that has a mean radius of $700 \mathrm{~m}$ (Figs. 4 and 5). The fan apex passes seaward into a narrow, deep trench which is closed by the third, youngest part of Lesina coastal barrier. The latter strip is about $400 \mathrm{~m}$ wide and marked by a close sequence of straight, sharp dunes. The remarkable continuity of this strip is broken only by a small washover fan at C. La Torre with a radius of $250 \mathrm{~m}$. The fan opens to the present shoreline through a narrow trench (Fig. 6).

\section{Discussion}

Washover fans form on a sandy coastal barriers when wavewash overcame dune crests in correspondence with breaches or throats forming distintictive fans. They are made of a wedge-shaped body with the maximum thickness of the washover sediment at the barrier crest. With major surge volume, the crest is often relocated landwards by sluicing overwash, and near continuous washover fans merging laterally into a washover flat (Orford and Carter, 1982).

The morphology of the Lesina coastal barrier (Fig. 7) indicates that at least three tsunamis struck the northern coast of Gargano Promontory in historical times. Each one deposited a washover fan 100000 to $750000 \mathrm{~m}^{2}$ in area that excludes the action of storm waves restricted by the small, semi-enclosed state of the Adriatic Sea and by the small tidal range (about $1 \mathrm{~m}$ ). The washover fans were formed by catastrophic tsunami waves focused at distinct points of coseismic 


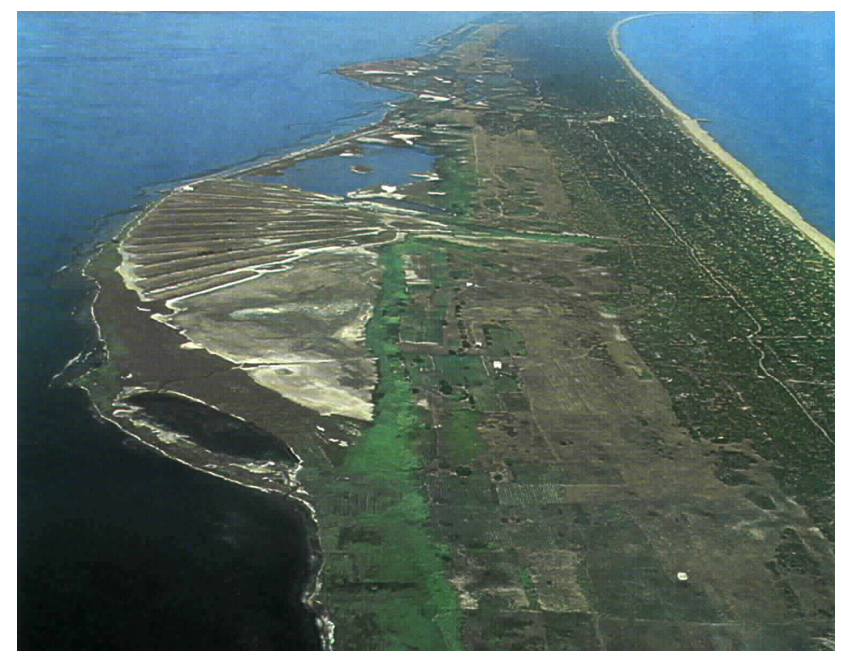

Fig. 4. A view of Foce Cauto washover fan. The geomorphological interpretation is shown in Fig. 5.

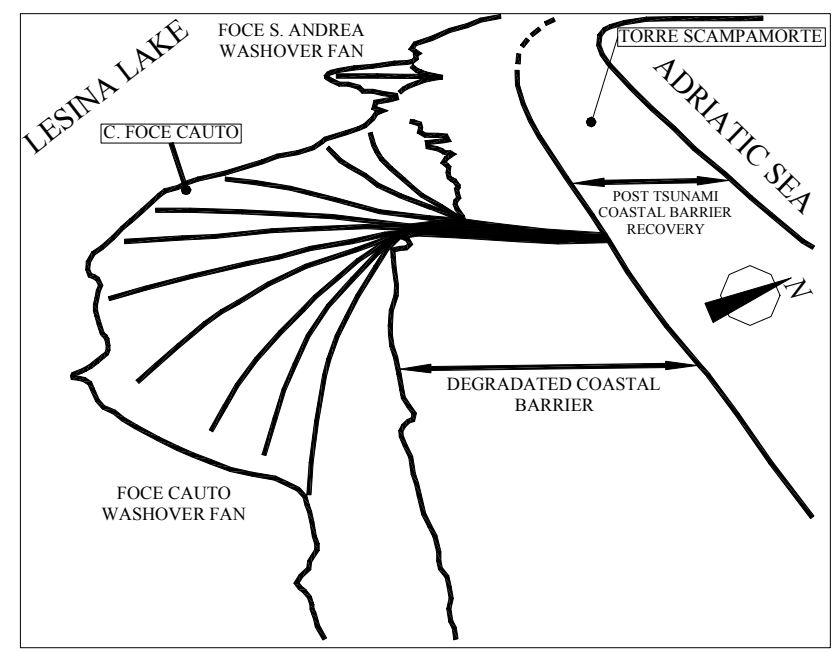

Fig. 5. The geomorphological interpretation of the Lesina coastal barrier in the area of Foce Cauto from Fig. 4.

cracking that developed into narrow, long breaches through coastal barrier ridges (Fig. 8a).

The formation of cracks was noted during the earthquake of the year 1627 at several localities near the epicentre, affecting the alluvial deposits and sands of the Fortore River lower valley and coastal plain (Molin and Margottini, 1981). These marks are similar to those reported following the Japan Sea earthquake and tsunami of 26 May 1983 (Minoura and Nakaya, 1991). Here, cracks that formed in the beaches and dunes separating Lake Jusan from the Japan Sea, allowed tsunami to rush into the back barrier area. At the Lesina coastal barrrier, during the second event, tsunami waves overtopped the coastal barrier levelling ridges and scoured a number of erosive grooves, similar to those reported by Sato et al. (1995) and McSaveney et al. (2000) during tsunami events. Sea water ran through the cracks, forming a nar-

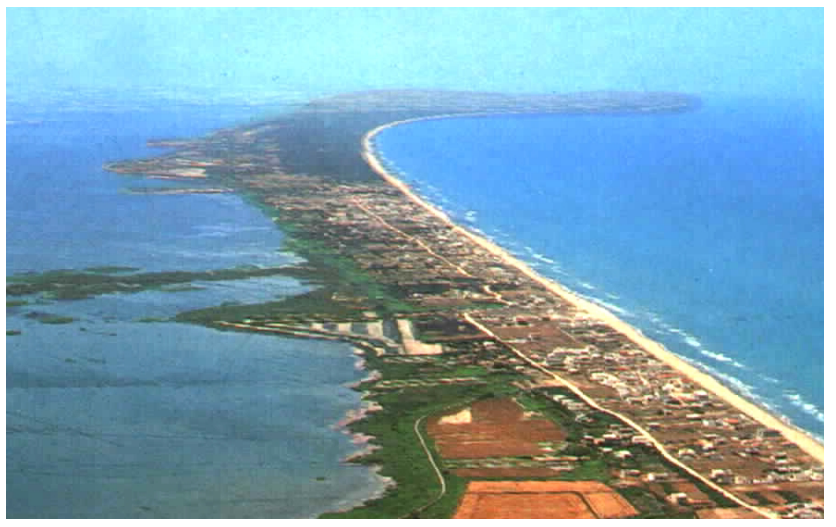

Fig. 6. A view of C. La Torre washover fan and the growing urbanization of the coastal barrier.

row throat and a wide washover fan at the inner edge of the coastal barrier. At the same time, the seaward edge of the coastal barrier was most likely cliffed and a significant amount of barrier sediment was moved offshore forming submarine bars (Fig. 8b). This is similar to processes observed by Maramai and Tinti (1997) during the 3 June 1994 Java tsunami, and by Minoura and Nakaya (1991) in the offshore area soon after the Japan Sea earthquake and tsunami of 26 May 1983. Normal wave climate was the final factor responsible for the transport of submarine bars onshore, causing the recovery of the coastal barrier and the formation of new dune ridges. These closed the washover throat and buried the cliff (Fig. 8c).

Morphological, archaeological and historical data allow a chronology of the tsunamis to be defined. The oldest tsunami and the first washover fan (S. Andrea fan) formation occurred before Roman times. It produced a gap in the coastal barrier that was exploited by the Romans to construct a waterway between the lake and the sea. The same waterway was still in use during medieval times with the name of Fuci Vetere (Di Perna, 1998) and during the XVI century, as shown by Gambacorta portolano drawings (1594). During this last period, the waterway was protected by Torre Foce, built in 1568 and later named Torre Scampamorte (meaning "tower of avoided death"). The Foce Cauto washover fan developed subsequentely. Its throat cuts across the dune ridges that closed the apex of the S. Andrea fan. Moreover, it should be older than the Torre Scampamorte construction, which is placed at the third and youngest part of the coastal barrier and which could not have survived such a catastrophic event. The small washover fan of C. La Torre was formed in very recent times since its throat cuts through the coastal barrier.

Two AMS radiocarbon age determinations have been performed at Geochron Laboratories on pulmonate gastropods with the aim of dating this sequence. Samples of Helix sp. and Pomatia sp. were collected on the crest of the dune ridges closing the washover throats of the S. Andrea (S. Andrea - 1 sample) and Foce Cauto (Cauto - 1 sample) fans. Results indicate an age of $2430 \pm 40$ years BP for the event 

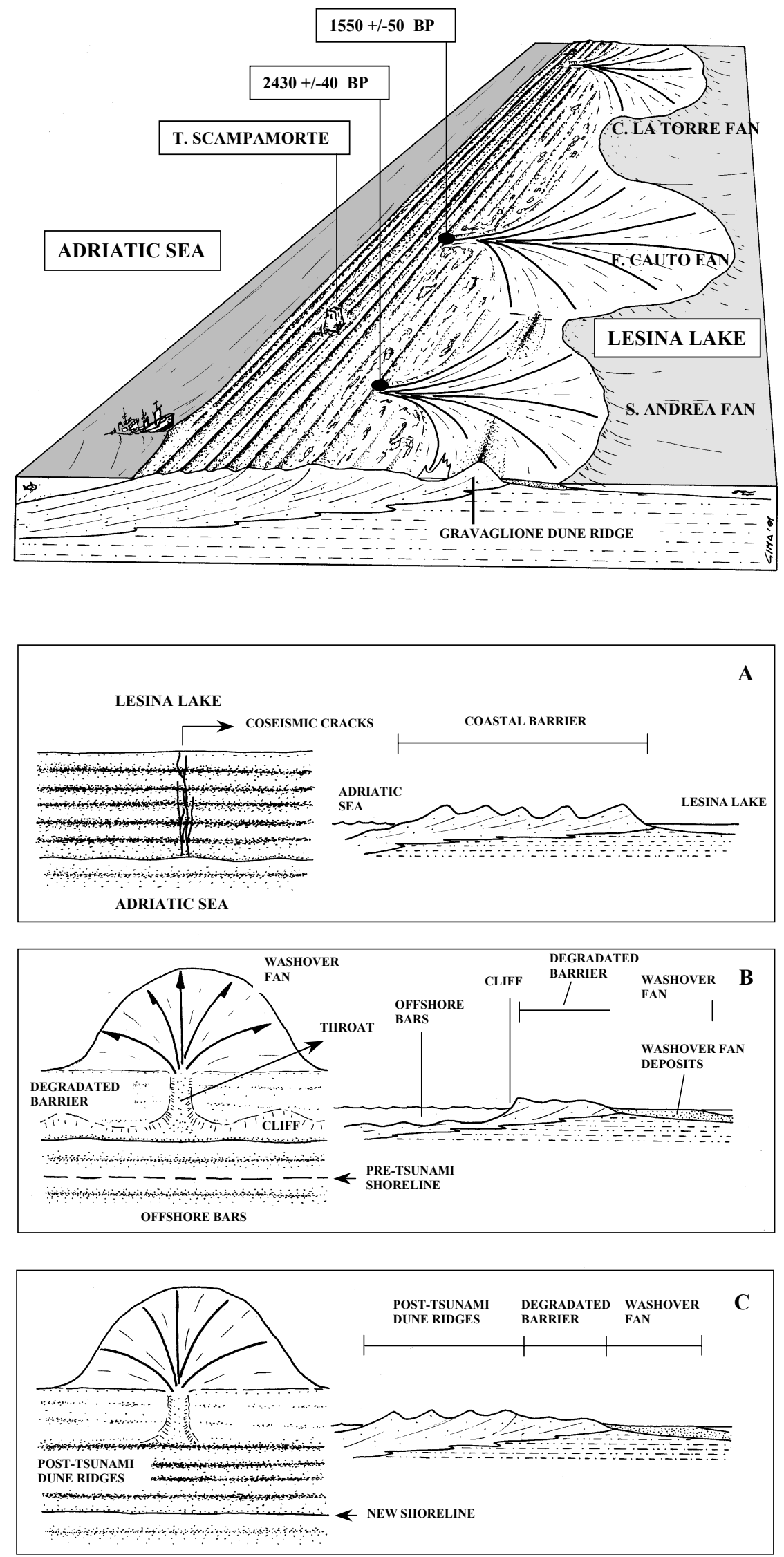

Fig. 7. Geomorphological sketch of the Lesina coastal barrier. The position of samples dated by means of AMS radiocarbon age determinations is also reported.
Fig. 8. Geomorphological model of tsunami impact on the Lesina coastal barrier. (a) Coseismic cracks formed in the coastal barrier dune ridges during an earthquake; (b) tsunami waves flatten the coastal barrier ridges. Sea water running through the cracks shapes a narrow throat and a wide washover fan at the inner edge of the coastal barrier. At the same time, a cliff is cut at the seaward edge of the coastal barrier and significant amounts of barrier sediments are moved offshore forming submarine bars. (c) Normal waves are the final factor responsible for the transport of submarine bars sediment onshore, causing the recovery of the coastal barrier with new dune ridges forming and closing the washover throat. 

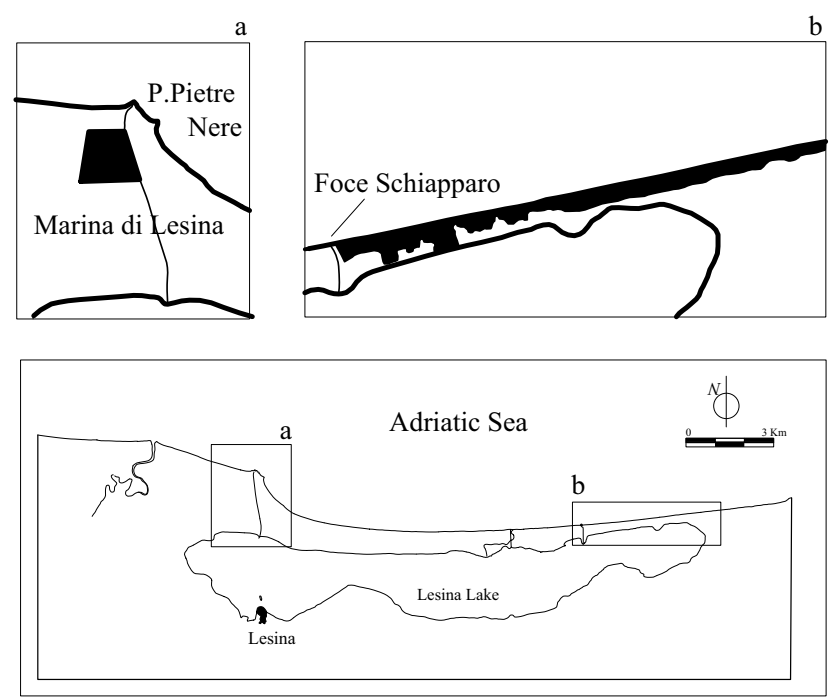

Fig. 9. Black areas mark the urbanized areas placed at the easternmost and westernmost part of Lesina coastal barrier.

responsible for S. Andrea washover fan development and $1550 \pm 50$ years BP for the formation of the Foce Cauto fan, confirming the reconstructed chronological framework. The relative calibrated ages of $736 \pm 20 \mathrm{cal} \mathrm{BC}$ and $488 \pm 55 \mathrm{cal}$ $\mathrm{AD}$, respectively, have been calculated using the CALIB 4.3 software (Stuiver and Reimer, 1993).

Both events are not documented in the historical chronicles and do not fit with any of the events reported by the most recent and updated catalogue of Italian strong earthquakes (Boschi et al., 2000). Nonetheless, a strong earthquake in the Gargano area is described in one of the most important medieval sacred legends and traditionally dated at the $493 \mathrm{AD}$. It was enclosed on this basis in the older earthquake catalogues (e.g. Bonito, 1691; Mercalli, 1883; Baratta, 1901). Recent structural data (Piccardi, 1998) suggest that this earthquake had a magnitude between 6 and 7 in the southern area of the Gargano Promontory. The present study supplies the first convincing evidence that the $493 \mathrm{AD}$ strong earthquake really occurred. It caused the tsunami that struck the Lesina coastal barrier, forming the Foce Cauto washover fan.

\section{Conclusions}

Three wide washover fans characterize the sandy coastal barrier that divides the Lesina coastal lake from the Adriatic Sea. They were formed due to the effective overwash of the coastal barrier by three tsunami waves during historical times. Tsunami wave erosion and deposition was controlled spatially by the formation of long coseismic cracks transversing the coastal barrier. Fans formed at the landward openings of narrow, long breaches. Each event was followed by a coastal barrier recovery phase that was responsible for the closing of the washover fan throats. The oldest tsunami event formed the S. Andrea washover fan and is pre-Roman in age,

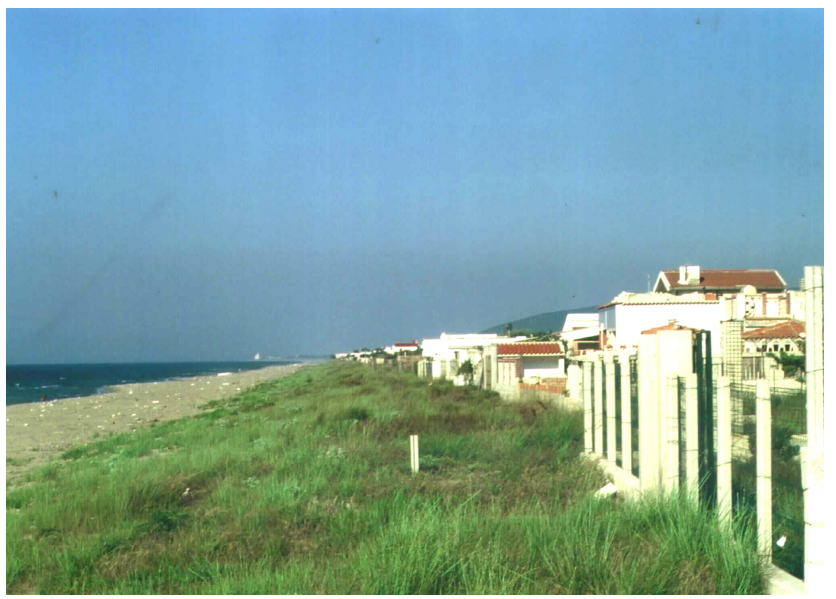

Fig. 10. A view of the growing urbanization on the Lesina coastal barrier.

at about 2430 years BP $(736 \pm 20 \mathrm{cal} \mathrm{BC})$. The second event had a similar magnitude and was responsible for the development of the Foce Cauto fan at 1550 years BP $(488 \pm 55$ cal $\mathrm{AD})$. It was caused by the strong eartquake that occurred on the Gargano Promontory in $493 \mathrm{AD}$ and reported by a medieval sacred legend. Finally, the C. La Torre washover fan formed during an event of minor intensity, most likely caused by the tsunami that struck the coast of northern Gargano on 30 July 1627.

These results indicate that the Lesina coastal barrier is not suitable for urban development since it has been struck by destructive tsunamis during its history, with a recurrence time of about one thousand years. Unfortunately, these catastrophic events have been completely neglected by planners, so that a recent, growing urbanization linked to the tourism industry has developed in the western-most and eastern-most parts of the Lesina coastal barrier (Figs. 9 and 10). This situation poses a significant risk to life and properties if another tsunami were to hit this area in the near future.

Acknowledgements. We warmly thank A. Lombardi and A. Gravina for their friendship, suggestions and archeological data. We also thank C. Varola and R. Sbarra for the revision of the English manuscript. Furthermore we thank C. Andrade and T. Bryant for their helpfull suggestings to improve this paper.

This research has been supported by MURST financial contribution $60 \%$ Project: "Variazioni del livello relativo del mare olocenico lungo la costa del basso Adriatico e dello Ionio: rischio e pericolositá lungo la fascia costiera" (Resp. D. Mastronuzzi).

This paper is an Italian contribution to IGCP 437 "Coastal Environmental Change During Sea-Level Highstands", Project Leader: C. Murray-Wallace.

\section{References}

Alvisi, G.: La viabilit romana della Daunia, Soc. Storia Patria per la Puglia, 36 (in Italian), 1970. 
Andrade, C.: Tsunami generated forms in the Algarve barrier islands, in: European Geophysical Society 1992 Tsunami Meeting, (Ed) Dawson A. G., Sci. Tsunami Hazards, 10, 21-34, 1992.

Baratta, M.: I terremoti d'Italia, Torino (in Italian), 1901.

Bonito, M.: Terra tremante, Napoli (in Italian), 1691.

Bourrouilh-Le Jan, F. G. and Talandier, J.: Sédimentation et fracturation de haute énergie en milieu récifal: Tsunamis, ouragans et cyclones et leurs effets sur la sédimentologie et la géomorphologie d'un atoll: motu et hoa, à Rangiroa, Tuamotu, SE Pacific), Marine Geology, 67, 263-333, 1985.

Boschi, E., Guidoboni, E., Ferrari, G., Mariotti, D., Valensise, G., and Gasperini, P. (Eds): Catalogue of strong Italian earthquakes from 461 B.C. to 1997, Annali di Geofisica, 43, 1-868, 2000.

Bryant, E. A. and Young, R. W.: Bedrock-Sculpturing by Tsunami, South Coast New South Wales, Australia, J. Geology, 104, 565582, 1996.

Bryant, E. A., Young, R. W., and Price, D. M.: Tsunami as a major control on coastal evolution, Southeastern Australia, J. Coast. Res., 12, 831-840, 1996.

Dawson, A. G.: Geomorphological effects of tsunami run-up and backwash, Geomorphology, 10, 83-94, 1994.

Dawson, A. G.: Linking tsunami deposits, submarine slides and offshore earthquakes, Quaternary International, 60, 119-126, 1999.

Dawson, A. G.: Tsunami deposits, Pure app. geophys., 157, 875897, 2000

Di Perna, G.: Lesina dal Paleolitico all'anno Mille, (Ed) Torraco, (in Italian), 1998

Gravina, A.: Torre Mileto fra Preistoria e Protostoria, in: "Il Gargano e il mare", Quaderni del Sud, 1-32 (in Italian), 1995.

Guidoboni, E. and Tinti, S.: I maremoti garganici del seicento, Atti VI Convegno GNGTS, 491-504 (in Italian), 1987.

Hearty, P. J.: Boulder deposits from large waves during Last Interglaciation on North Eleuthera Island, Bahamas, Quaternary Research, 48, 326-338, 1997.

Hearty, P. J.: Chevron ridges and runup deposits in the Bahamas from Storms late in Oxygen-Isotope Substage 5e, Quaternary Research, 50, 309-322, 1998.

Maramai, A. and Tinti, S.: The 3 June 1994 Java tsunami: a postevent survey of the coastal effects, Natural Hazards, 15, 31-49, 1997.

Mastronuzzi, G. and Sansò, P.: Boulders transport by catastrophic waves along the Ionian coast of Apulia (southern Italy), Marine Geology, 170, 93-103, 2000.

McSaveney, M. J., Goff, J. R., Darby, D. J., Goldsmith, P., Barnett, A., Elliott, S., and Nongkas, M.: The 17 July 1998 tsunami, Papua New Guinea: evidence and initial interpretation, Marine
Geology, 170, 81-92, 2000.

Mercalli G.: Vulcani e fenomeni vulcanici in Italia, Milano (in Italian), 1883.

Minoura, K. and Nakaya, S.: Traces of tsunami preserved in intertidal lacustrine and marsh deposits: some examples from Northeast Japan, J. Geology, 99, 265-287, 1991.

Molin, D. and Margottini, C.: Il terremoto del 1627 nella Capitanata settentrionale, Memorie Conv. Ann. PFG-CNR, 251-279 (in Italian), 1981.

Moore, J. G. and Moore, G. W.: Deposit from a giant wave on the island of Lanai, Hawaii, Science, 226, 1311-1315, 1984.

Moore, G. W. and Moore, J. G.: Large-scale bedforms in boulder gravel produced by giant waves in Hawaii, In: Sedimentologic Consequences of Convulsive Geologic Events, (Ed) Clifton, H. E., Geol. Soc. Am. Spec. Pap., 229, 101-110, 1988.

Nakata, T. and Kawana, T.: Historical and prehistoric large tsunamis in the southern Ryukyus, Japan, in: Tsunami'93, Proc. IUGG/IOC Int. Tsunami Symp., Wakayama, Japan, 23-27 August 297-307, 1993.

Orford, J. D. and Carter, R. W. G.: Crestal overtop and washover sedimentation on a fringing sandy gravel barrier coast, Carnsore Point, Southeast Ireland, J. Sediment. Petrol., 52, 265-278, 1982.

Ota, Y., Pirazzoli, P. A., Kawana, T., and Moriwaki, H.: Late Holocene coastal morphology and sea-level records on three small islands, the South Ryukyus, Japan, Geogr. Rev. Jpn., 58B, 185-194, 1985.

Piccardi, L.: Cinematica attuale, comportamento sismico e sismologia storica della faglia di Monte Sant'Angelo (Gargano, Italia): la possibile rottura superficiale del "leggendario" terremoto del 493 DC, Geogr. Fis. Dinam. Quat., 21, 155-166 (in Italian), 1998.

Sato, H., Shimamoto, T., Tsutsumi, A., and Kawamoto, E.: Onshore Tsunami Deposits Caused by the 1993 Southwest Hokkaido and 1983 Japan Sea Earthquakes, PAGEOPH, 144, 693-71, 1995.

Stuiver, M. and Reimer, P. J.; Extended 14C database and revised CALIB radiocarbon calibration program, Radiocarbon, 35, 215 230, 1993.

Tinti, S. and Platanesi, A.: Numerical simulation of the tsunami induced by the 1627 earthquake affecting Gargano, Southern Italy, J. Geodynamics, 21, 141-160, 1996.

Tinti, S., Maramai, A., and Favali, P.: The Gargano promontory: An important Italian seismogenic-tsunamigenic area, Marine Geology, 122, 227-241, 1995.

Young, R. W., Bryant, E. A., and Price, D. M.: Catastrophic wave (tsunami?) transport of boulders in southern New South Wales, Australia, Z. Geomorph., 40, 2, 191-207, 1996. 